\title{
SURFACE PROPERTIES OF CELLS OF SOME METHICILLIN-RESISTANT STRAINS OF STAPHYLOCOCCUS AUREUS
}

\author{
G. N. Vernon and A. D. Russell \\ Welsh School of Pharmacy, University of Wales Institute of Science and Technology, \\ Cathays Park, Cardiff, CF1 3NU, U. K.
}

(Received for publication July 19, 1977)

\begin{abstract}
Methicillin-sensitive (MS) cells of Staphylococcus aureus had a minimum electrophoretic mobility at $\mathrm{pH} 4.5$, whereas methicillin-resistant (MR) strains showed only a slight plateau effect. Trypsin removed the trough effect of the MS Oxford strain. There was no correlation between surface lipid and resistance in MR strains. Cell walls of MS strains contained much more teichoic acid than walls of MR strains. Lysostaphin lysed all MR and MS strains, and mucopeptide does not appear to be involved in resistance to methicillin.
\end{abstract}

Methicillin-resistant (MR) strains of Staphylococcus aureus have been a problem in chemotherapy for more than 10 years. Surprisingly little attention, however, has been devoted to an understanding of the basic reaction(s) for the high resistance of these strains.

MR strains are characterized by the fact that, at $37^{\circ} \mathrm{C}$, a small proportion of the cells is resistant to methicillin and other $\beta$-lactam antibiotics, whereas at $25^{\circ} \mathrm{C}$ the majority of cells in a culture are resistant $^{1 \sim 4)}$. It is the temperature at which the cells are treated with methicillin and not the pretreatment growth temperature which is of paramount importance ${ }^{5}$.

This paper investigates the surface properties of cells of MR strains of S. aureus in relation to those of the methicillin-sensitive (MS) Oxford strain.

\section{Materials and Methods}

Strains: The following S. aureus strains were kindly supplied by Dr. E. AsHeshov (Public Health Laboratories, Colindale, London): $7270+, 7270-, 9254+, 9254-$. The + ve sign indicates a $\beta$ lactamase producer, the -ve sign the absence of $\beta$-lactamase. All were received as MR strains, but 9254 - was found subsequently to be MS. The Oxford strain, NCTC 6571, of $S$. aureus which is highly sensitive to $\beta$-lactam antibiotics was used as a control.

Electrophoretic mobility: Measurement of electrophoretic mobility ${ }^{6)}$ was made at $25^{\circ} \mathrm{C}$ in veronal acetate buffer pH $3 \sim 7(\mathrm{I}=0.02 \mathrm{M})$ in a microelectrophoresis apparatus (Rank Brothers Ltd., Cambridge, England).

Surface protein: Cultures grown at $25^{\circ} \mathrm{C}$ or $37^{\circ} \mathrm{C}$ were centrifuged, and the cells washed with, and suspended in, $20 \mathrm{ml}$ of $0.85 \% \mathrm{w} / \mathrm{v}$ sodium chloride. The suspension was divided into two portions, centrifuged, and the supernatant fluid removed. One pellet was resuspended in $20 \mathrm{ml}$ SörENSEN's phosphate buffer $(\mathrm{I}=0.11 \mathrm{M}) \mathrm{pH} 8$, and the other in $20 \mathrm{ml}$ of this buffer containing $0.01 \%$ crystalline trypsin (Koch-Light Ltd., Colbrook, Berkshire, England). Both portions were incubated at $37^{\circ} \mathrm{C}$ for 2 hours. The cells were then washed twice with $10 \mathrm{ml}$ veronal acetate buffer $(I=0.02 \mathrm{M}) \mathrm{pH} 7$ and subsequently suspended in veronal acetate buffer $(I=0.02 \mathrm{M})$ of the required $\mathrm{pH}$ at $25^{\circ} \mathrm{C}$. Electrophoretic mobilities were determined, and the T-value calculated: this is the percentage increase in mobility at $\mathrm{pH} 4.5$.

Surface lipid: Cultures grown at $25^{\circ} \mathrm{C}$ or $37^{\circ} \mathrm{C}$ were centrifuged. The cells were washed with $20 \mathrm{ml}$ of glass-distilled water and then $20 \mathrm{ml}$ of veronal acetate buffer $(\mathrm{I}=0.02 \mathrm{M}) \mathrm{pH}$. Finally, the 
cells were resuspended in $10 \mathrm{ml}$ of this buffer at $25^{\circ} \mathrm{C}$. When required $0.5 \mathrm{ml}$ was added to $9.5 \mathrm{ml}$ of buffer containing the appropriate concentration of sodium lauryl sulphate (SLS; B.D.H. Chemicals Ltd., Poole, Dorset, England) at $25^{\circ} \mathrm{C}$. Electrophoretic mobilities were determined and the S-value ${ }^{\text {7) }}$ calculated: this is the percentage increase in mobility in the presence of $10^{-4} \mathrm{M}$ SLS.

Surface properties of methicillin-treated cells: When shaken cultures of MR strains are exposed to inhibitory doses of methicillin, confluent growth occurs at 24 hours $^{5)}$. The present experiment was undertaken to study the surface properties of cells surviving exposure at $37^{\circ} \mathrm{C}$ to methicillin concentrations of $1 / 3,3 / 5$ and $8 / 5$ times the minimum inhibitory concentration (MIC). Cells were grown in nutrient medium in shaken flasks containing methicillin ${ }^{5}$. After 24 hours, the cells were harvested, washed twice with glass-distilled water and finally resuspended in $20 \mathrm{ml}$ water; $0.4 \mathrm{ml}$ of suspension was added to $10 \mathrm{ml}$ veronal acetate buffer, $\mathrm{pH} 3 \sim 7$, previously equilibrated at $25^{\circ} \mathrm{C}$, and electrophoretic mobility measured.

Cell wall preparation: Twenty liters of nutrient broth no. 2 (Oxoid Ltd., London) in a large fermentor were inoculated with $250 \mathrm{ml}$ of a culture and incubated at the appropriate temperature for 18 hours. In some experiments, methicillin was included in the media. The cells were harvested by centrifugation. Cell walls were prepared by means of the X-press ${ }^{8)}$. Examination by ultraviolet absorption at $260 \mathrm{~nm}$ and by electron microscopy indicated that the walls were free from nucleic acid contamination and from whole cells and other visible contaminants.

Quantitative extraction and purification of teichoic acid: The method used was based upon that of BADDILEY et $a l^{9}$, using $10 \%$ trichloroacetic acid. Chromatographic identification of teichoic acid components was made with an acid ( $2 \mathrm{~N}$ hydrochloric) hydrolysate on activated silica gel plates ${ }^{10}$.

Removal of surface teichoic acid from cells: Cultures were grown at $25^{\circ} \mathrm{C}$ or $37^{\circ} \mathrm{C}$, and their cells washed once in $20 \mathrm{ml}$ glass-distilled water and then in $20 \mathrm{ml}$ of $0.85 \% \mathrm{w} / \mathrm{v}$ sodium chloride. Twenty $\mathrm{ml}$ of $0.1 \mathrm{M}$ ammonia were added to remove any ester-linked alanine and left for 5 minutes at $20^{\circ} \mathrm{C}$. The suspension was centrifuged and the cells washed with $20 \mathrm{ml}$ water. After centrifugation, the cells were suspended in $20 \mathrm{ml}$ of MichaeLis buffer $(I=0.02 \mathrm{M}) \mathrm{pH} 6$ containing the oxidising agent sodium metaperiodate (for removal of teichoic acid), and held for 30 minutes at $37^{\circ} \mathrm{C}$.

The cells were centrifuged, washed twice in $20 \mathrm{ml}$ water and finally resuspended in $15 \mathrm{ml}$ water, then $0.7 \mathrm{ml}$ of this suspension was added to $9 \mathrm{ml}$ of each buffer solution at $25^{\circ} \mathrm{C}$ for the measurement of electrophoretic mobilities.

Effect of lysostaphin: Lysostaphin ${ }^{11)}$ was tested against whole cells, cell walls and mucopeptide obtained from walls after removal of teichoic acid. Changes in extinction were measured at $620 \mathrm{~nm}$ in the SP 600 spectrophotometer. Minimum inhibitory concentrations (MIC's) of lysostaphin against the strains were determined at $25^{\circ} \mathrm{C}$ and $37^{\circ} \mathrm{C}$.

\section{Results}

\section{Electrophoretic Studies}

Fig. 1 indicates that, in nearly all cases, as the $\mathrm{pH}$ was decreased the mobility of the cells decreased. MS strains grown at $37^{\circ} \mathrm{C}$ had a minimum mobility (trough effect) at $\mathrm{pH} 4.5$, whereas the MR strains showed only a slight plateau effect. Between pH 6 and 7, there was usually a decrease in mobility or a plateau effect. Cells of a particular strain grown overnight at $25^{\circ} \mathrm{C}$ tended to have a higher mobility than those likewise grown at $37^{\circ} \mathrm{C}$, possibly the result of difference in the configuration of the teichoic acid. Treatment of cells with trypsin (not shown) did not remove the plateau or trough effect, except with the Oxford strain. The increases in mobility of the strains at $\mathrm{pH} 4.5$ are shown as the T-value in Table 1; this is highly significant only with the Oxford strain and with strain $9254-$ grown at $37^{\circ} \mathrm{C}$.

The mobility of cells containing surface lipid is altered by treatment with a surface-active agent such as $\operatorname{SLS}^{12)}$. S-values are listed in Table 1 , a value $>10$ indicating the presence of surface lipid ${ }^{7}$. 
The two MS strains contained significantly more surface lipid than the MR strains and in only one MR strain $(7270-$, grown at $37^{\circ} \mathrm{C}$ ) was the S-value $>10$.

The electrophoretic mobilities of methicillintreated cells are shown in Fig. 2. For most strains the mobility curves of cultures exposed to $3 / 5 \times$ MIC of methicillin were very similar to those of untreated cells. However, the curves of cultures exposed to $8 / 5 \times$ the MIC were markedly different, indicating that the surfaces of those cells differed from those of control (untreated) cells.

The effects of $\mathrm{pH}$ on the electrophoretic mobilities of cells from which surface teichoic acid had been removed by means of sodium periodate are shown in Fig. 3. Every strain, irrespective of growth temperature, had an increased mobility with increasing $\mathrm{pH}$, but the trough and plateau responses see in "normal" MS or MR cells (Fig. 1) were not observed.

\section{Cell-Wall Composition}

Chromatographic analyses of teichoic acid hydrolysates demonstrated the presence of ribitol, $\mathrm{N}$-acetylglucosamine, D-alanine and glucosamine in all strains; no glycerol was found, indicating that the extracted teichoic acid was of the ribitol moiety.

Quantitative studies on the amount of teichoic acid present in the walls of each strain gave the results presented in Table 2. The amount of teichoic acid in the walls of cells grown at $25^{\circ} \mathrm{C}$ was always somewhat higher than in the walls of $37^{\circ} \mathrm{C}$ grown cells, and the walls of MS cells contained considerably greater contents of teichoic acid than did those of MR cells. Methicillin caused a reduction in the teichoic acid content of the walls of the two MS strains.

\section{Effect of Lysostaphin}

MIC values $(\mu \mathrm{g} / \mathrm{ml})$ of lysostaphin at, respectively, $25^{\circ} \mathrm{C}$ and $37^{\circ} \mathrm{C}$ against the various strains were: 
$7270+, 12.8$ and $6.4 ; 7270-, 12.8$ and $6.4 ; 9254+, 12.8$ and 6.4; 9254-, 12.8 and 6.4; Oxford, 6.4 and 3.2. Rates of lysis of four of these strains exposed to lysostaphin are provided in Fig. 4. Lysis was most rapid with whole cells, and least with isolated mucopeptide (possibly because of some degradation during preparation). With all strains, lysis tended to be somewhat greater with cells or their components from cultures grown at $37^{\circ} \mathrm{C}$.

\section{Discussion}

As the $\mathrm{pH}$ decreased, the electrophoretic mobility of the cells decreased (Fig. 1). At low pH values, protonation of the negatively charged phosphate groups and the positively charged amino groups of teichoic acids occurs; as the $\mathrm{pH}$ increases, the amount of protonation decreases and the negative surface charge increases.

Although a relationship between surface or cell wall lipid and resistance to antibiotics has been found in $S$. aureus ${ }^{13)}$, the results in the present paper suggest that wall lipid is not involved in resistance to methicillin. Likewise, studies involving lysostaphin indicate that mucopeptide appears to be unimportant in this content, and this agrees with the earlier findings of DYKE ${ }^{2)}$.

Rather more teichoic acid has been found in the walls of MR strains grown at $25^{\circ} \mathrm{C}$ than in those grown at $37^{\circ} \mathrm{C}$, but it is to be wondered how significant this is. Our results differ somewhat in this context from those of JAMES and his colleagues $^{7,14,15)}$. Nevertheless, there are significant differences in the relative amounts of teichoic acid in the walls of MR and MS cells. It is also
Fig. 2. pH-Mobility curves of cells of strains of $S$. aureus treated with inhibitory and subinhibitory doses of methicillin at $37^{\circ} \mathrm{C}$.

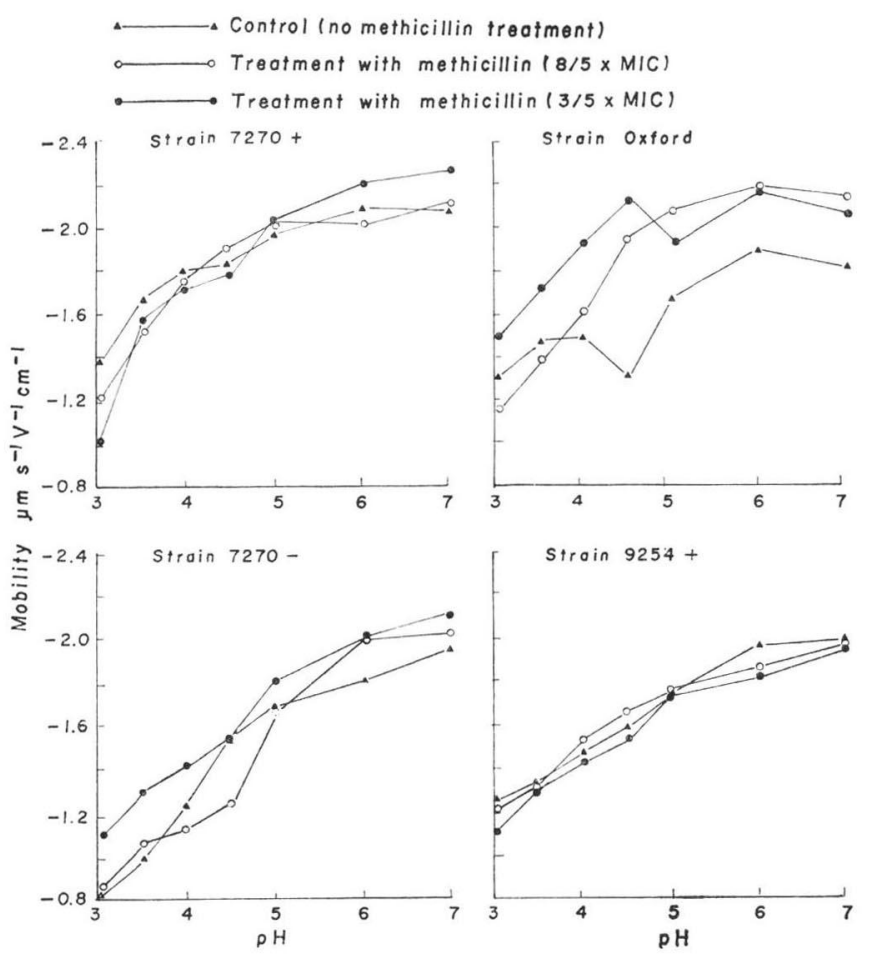

Fig. 3. pH-Mobility curves of $S$. aureus strains grown overnight at $25^{\circ} \mathrm{C}$ or $37^{\circ} \mathrm{C}$ and then treated with sodium metaperiodate.
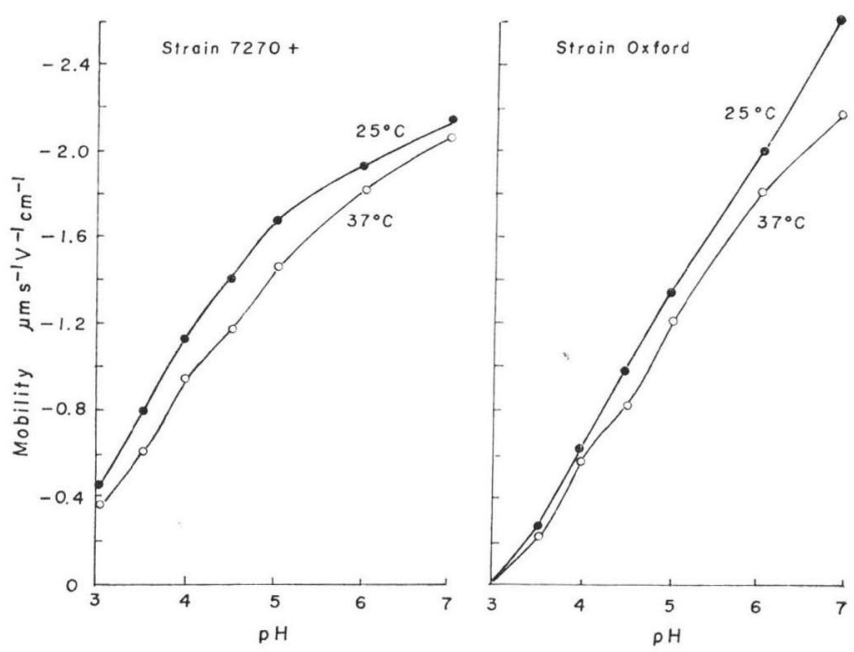
Table 2. Teichoic acid content of the cell walls of $S$. aureus strains

\begin{tabular}{c|c|c}
\hline Strain & $\begin{array}{c}\text { Growth } \\
\text { temperature } \\
\left({ }^{\circ} \mathrm{C}\right)\end{array}$ & $\begin{array}{c}\text { Teichoic acids } \\
\text { as \% of } \\
\text { cell wall }\end{array}$ \\
\hline $7270+$ & 25 & 19.8 \\
$7270-$ & 37 & 18.4 \\
$9254+$ & 25 & 19.2 \\
& 37 & 15.8 \\
$9254-$ & 25 & 20.5 \\
& 37 & 17.6 \\
Oxford & 25 & 42 \\
& 37 & 28 \\
& $37 *$ & 21 \\
& 25 & 32 \\
\hline
\end{tabular}

* Growth in presence of methicillin, 8/5 $\times$ MIC (see Ref. 5)
Fig. 4. Effect of lysostaphin $(50 \mu \mathrm{g} / \mathrm{ml})$ at $20^{\circ} \mathrm{C}$ on whole cells, cell walls and mucopeptide of $S$. aureus: (a) strain $7270+$, (b) strain $7270-$, (c) strain $9254+$, (d) strain Oxford.

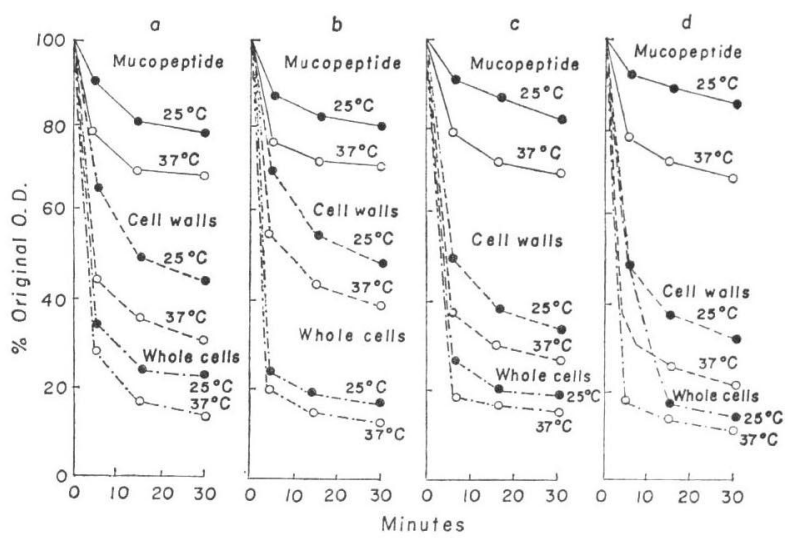

pertinent to note, however, that there are also considerable differences between the cell wall protein content of the MS Oxford strain and the MR strains.

\section{Acknowledgements}

We thank the Welsh Office for a research studentship to one of us (G.N.V.).

\section{References}

1) Annear, D. I.: The effects of temperature on resistance of Staphylococcus aureus to methicillin and some other antibiotics. Med. J. Austral. 1: $444 \sim 446,1968$

2) Dyke, K. G. H.: Penicillinase production and intrinsic resistance to penicillins in methicillin-resistant cultures of Staphylococcus aureus. J. Med. Microb. 2: $261 \sim 278,1969$

3) Hewitt, J. H.; A. W. Coe \& M. T. Parker: The detection of methicillin resistance in Staphylococcus aureus. J. Med. Microb. 2: 443 456, 1969

4) Hewitt, J. H. \& P. J. Sanderson: Methicillin-resistant Staphylococcus aureus. Lancent 1974-1: 415 416,1974

5) Vernon, G. N. \& A. D. Russell: Effects of methicillin, cephaloridine and cephalothin on the growth, lysis and viability of some methicillin-resistant strains of Staphylococcus aureus. J. Antimicr. Chemoth. 2: $41 \sim 48,1976$

6) Munton, T. J. \& A. D. Russell: Aspects of the action of glutaraldehyde on Escherichia coli. J. Appl. Bact. 33: $410 \sim 419,1970$

7) Marshall, N. J. \& A. M. James: Surface properties of methicillin-resistant cells of Staphylococcus aureus. Microbios 4: $217 \sim 225,1971$

8) Haque, H. \& A. D. Russell: Cell envelopes of gram-negative bacteria: Composition, response to chelating agents, and susceptibility of whole cells to antibacterial agents. J. Appl. Bact. 40: 89 99, 1976

9) Baddiley, J.; J. G. Buchanan, R. D. Martin \& U. L. Rajbhandary: Teichoic acid from the walls of Staphylococcus aureus H. II. Location of phosphate and alanine residues. Biochem. J. 85: 49 56, 1962

10) Armstrong, J. J.; J. Baddiley \& J. G. Buchanan: Structure of the ribitol teichoic acid from the walls of Bacillus subtilis. Biochem. J. 76: 610 621, 1960

11) Schindler, C. A. \& V. T. Schuhardt: Lysostaphin: A new bacteriolytic agent for the staphylococcus. Proc. Nat. Acad. Sci. U.S. 51: $414 \sim 421,1964$

12) Dyar, M. T. \& E. J. ORdal: Electrokinetic studies on bacterial surfaces. I. The effects of surface-active agents on the electrophoretic mobilities of bacteria. J. Bact. 51: 149 167, 1946

13) Hugo, W. B. \& R. J. Stretton: The role of cellular lipid in the resistance of gram-positive bacteria to penicillins. J. Gen. Microbiol. 42: 133 138, 1966 
14) Hill, A. W. \& A. M. JAmES: Surface properties of cells of methicillin-sensitive and -resistant strains of Staphylococcus aureus grown at $37^{\circ} \mathrm{C}$. Microbios 6: $157 \sim 167,1972$

15) Davies, A. L. \& A. M. JAmes: Phosphatase activity of methicillin-resistant and methicillin-sensitive cells of Staphylococcus aureus. Microbios 10: 257 268, 1974 